\title{
SERBUK GERGAJI KAYU JATI TERAKTIVASI EDTA SEBAGAI PENJERAP ION TEMBAGA (II) DAN KROM (III)
}

\author{
Teak Sawdust Activated by EDTA for Adsorption of Copper (II) and \\ Chromium (III) Ions
}

\author{
Irdhawati*, Ni Nyoman Triyunita Sinthadevi, Emmy Sahara \\ Department of Chemistry, Faculty of Mathematic and Natural Science, Udayana University, Kampus Bukit \\ Jimbaran Bali 80361 Indonesia \\ *Corresponding author, e-mail: irdhawati@unud.ac.id
}

Received: Oct. 2019 Published: Jan. 2020

\begin{abstract}
Teak sawdust is a waste of the furniture industry. The main compound content is cellulose, which contains hydroxyl groups so that can be used as adsorbent. This work aims to determine adsorption capacity and isotherm adsorption pattern of teak sawdust activated by EDTA for copper (II) dan chromium (III) ions. Some parameters were optimized including the ratio of adsorbent and EDTA, and contact time. The results showed the optimum ratio of teak sawdust and EDTA was 2:3, and the optimum contact time was 105 minutes. Both of isoterm adsorption patterns of teak sawdust to $\mathrm{Cu}$ (II) and $\mathrm{Cr}$ (III) ions follow the Freundlich equation, with determination coefficient close to one. Optimum adsorption capacity was obtained 46.5 and $39.7 \mathrm{mg} / \mathrm{g}$ for $\mathrm{Cu}$ (II) and $\mathrm{Cr}$ (III), respectively.
\end{abstract}

Keywords: Adsorbent, adsorption capacity, copper (II) ion, chromium (III) ion, teak sawdust.

\section{PENDAHULUAN}

Perkembangan industri di Indonesia sangat pesat, sehingga menyebabkan pencemaran lingkungan meningkat akibat belum adanya pengolahan limbah secara benar oleh pihak industri, khususnya limbah cair. Limbah cair dari beberapa industri seperti industri zat warna tekstil, cat, dan metalurgi, dapat menyebabkan pencemaran air oleh logam-logam berat, khususnya logam $\mathrm{Cu}$ (II). Logam $\mathrm{Cu}$ (II) akan memberikan efek toksik pada organisme apabila masuk ke dalam tubuh dalam jumlah yang melebihi batas toleransi organisme tersebut. Terlalu banyak logam $\mathrm{Cu}(\mathrm{II})$ dalam air dapat merusak organisme laut dan air tawar seperti ikan dan moluska. Selain terhadap organisme laut, apabila air yang tercemar $\mathrm{Cu}(\mathrm{II})$ dikonsumsi oleh organisme lainnya secara berlebihan dapat menyebabkan kerusakan hati dan ginjal. Berbagai metode pengolahan limbah telah dilakukan untuk mengurangi kadar logam berat dalam perairan antara lain metode pengendapan (Joko, 2013) dan elektrokimia (Pratiwi dkk., 2015). Metodemetode tersebut menggunakan bahan-bahan kimia yang mahal sehingga membutuhkan biaya yang tinggi. Oleh karena itu, perlu dilakukan penelusuran terhadap bahan penjerap baru yang relatif lebih murah, mudah didapat serta mempunyai kapasitas adsorpsi yang tinggi. Metode adsorpsi telah banyak dikembangkan menggunakan material alam organik yang memiliki gugus hidroksil (-OH) yang dapat digunakan untuk adsorpsi ion-ion logam berat, seperti kulit salak (Wijayanti dkk., 2017) dan kulit kacang tanah (Andini dkk., 2016). Salah satu material alam organik yang mengandung gugus hidroksil $(-\mathrm{OH})$ yang dapat digunakan sebagai adsorben yaitu serbuk gergaji kayu jati (Fengel dan Wegener, 1995).

Komponen kayu terdiri atas lapisan luar dan dalam. Pada lapisan luar terdiri dari zat ekstraktif yang dihasilkan kayu selama pertumbuhan, dan lapisan dalam terdiri atas selulosa, hemiselulosa, dan lignin (Fengel dan Wegener, 1995). Adanya selulosa, hemiselulosa dan lignin menjadikan serbuk gergaji kayu berpotensi sebagai bahan penjerap. Untuk meningkatkan kapasitas adsorpsi suatu adsorben perlu dilakukan aktivasi maupun modifikasi baik secara kimia maupun fisika. Berdasarkan penelitian Harni dkk. (2013) 
menggunakan serbuk gergaji kayu jati dengan aktivator : asam asetat, EDTA, formaldehida, dan piridin sebagai adsorben logam timbal $(\mathrm{Pb})$, diperoleh waktu kontak optimum semua aktivator yaitu 60 menit dengan kapasitas adsorpsi pada kontrol $0,1608 \mathrm{mg} / \mathrm{g}$, delignifikasi $0,2401 \mathrm{mg} / \mathrm{g}$, asam asetat $0,2717 \mathrm{mg} / \mathrm{g}$, EDTA $0,2965 \mathrm{mg} / \mathrm{g}$, formaldehida $0,2945 \mathrm{mg} / \mathrm{g}$, dan piridin 0,2857 $\mathrm{mg} / \mathrm{g}$, dengan kapasitas adsorpsi terbesar yaitu pada aktivasi dengan EDTA. Pada aktivasi EDTA yang memiliki 4 gugus asam karboksilat $(-\mathrm{COOH})$ akan bereaksi dengan lignoselulosa pada serbuk kayu dan mengaktifkan gugus $\mathrm{OH}$ yang terbentuk pada adsorben sehingga dapat mengadsorpsi ion logam $\mathrm{Pb}$ lebih banyak.

Berdasarkan latar belakang di atas, dalam penelitian ini digunakan serbuk gergaji kayu jati sebagai adsorben menggunakan EDTA sebagai aktivator dengan uji parameter yang mempengaruhi kapasitas adsorpsi yaitu aktivasi, waktu kontak dan isoterm adsorpsi. Oleh karena itu dilakukan penelitian mengenai pemanfaatan serbuk gergaji kayu jati teraktivasi EDTA dalam adsorpsi ion logam $\mathrm{Cu}$ (II). Kadar logam $\mathrm{Cu}$ (II) yang tidak teradsorpsi ditentukan dengan metode Spektrofotometri Serapan Atom.

\section{METODOLOGI}

Alat

Spektrofotometer Serapan Atom (Shimatzu AA-7000), oven (Binder), neraca analitik (Ohaus G400-S0 dan ACIS AD-600i), seperangkat alat refluks, magnetic stirrer, ayakan ukuran 100 mesh, dan peralatan gelas yang umum digunakan dalam laboratorium.

\section{Bahan}

Serbuk gergaji kayu jati, $\mathrm{CuCl}_{2}$ (Merck), $\mathrm{CrCl}_{3} .6 \mathrm{H}_{2} \mathrm{O}$ (Merck) Na $\mathrm{NaDTA}_{2}$ (Merck), $\mathrm{HCl}$ (Merck), $\mathrm{NaOH}$ (Merck), aquades, dan kertas saring

\section{Prosedur Kerja \\ Persiapan serbuk gergaji kayu jati sebagai sampel penelitian}

Serbuk gergaji kayu jati yang diambil dari pengrajin furniture dicuci dengan aquades untuk menghilangkan pengotor kemudian dikeringkan dalam oven dengan suhu $50{ }^{\circ} \mathrm{C}$ sampai kering. Selanjutnya dihaluskan dan diayak hingga berukuran 100 mesh.

\section{Aktivasi serbuk gergaji kayu jati}

Serbuk gergaji kayu jati (SJ) ditimbang sebanyak 20 gram dan dimasukkan ke dalam labu alas bulat $250 \mathrm{~mL}$ dan ditambahkan $200 \mathrm{~mL}$ larutan EDTA 5\%. Campuran direfluks selama 2 jam pada suhu $100^{\circ} \mathrm{C}$. Serbuk kayu jati yang telah diaktivasi kemudian disaring dan dikeringkan dalam oven pada suhuh $50{ }^{\circ} \mathrm{C}$. Prosedur yang sama dilakukan untuk konsentrasi EDTA 10; 15; dan 20\%. Masing-masing serbuk gergaji kayu jati yang diaktivasi EDTA 5; 10; 15; dan $20 \%$ diberikan label secara berturut-turut yaitu $\mathrm{SJ}_{\text {[EDTA5] }}, \mathrm{SJ}_{\text {[EDTA10] }}, \mathrm{SJ}_{\text {[EDTA15] }}$, dan $\mathrm{SJ}_{\text {[EDTA20] }}$.

\section{Pembuatan kurva kalibrasi}

Larutan standar $\mathrm{Cu}$ (II) dan $\mathrm{Cr}(\mathrm{III})$ dengan konsentrasi 1, 2, 3, 4, dan $5 \mathrm{mg} / \mathrm{L}$ diukur absorbansinya dengan Spektrofotometer Serapan Atom (SSA). Selanjutnya dibuat kurva hubungan antara absorbansi versus konsentrasi yang akan diperoleh garis linier.

\section{Penentuan jumlah EDTA optimum sebagai aktivator}

Sebanyak 1-gram $\quad \mathrm{SJ}_{\text {[EDTA5] }}, \quad \mathrm{SJ}_{\text {[EDTA10] }}$, $\mathrm{SJ}_{\text {[EDTA15], }}$ dan $\mathrm{SJ}_{\text {[EDTA20] }}$ masing-masing dimasukkan ke dalam labu erlenmeyer. Selanjutnya ditambahkan $50 \mathrm{~mL}$ campuran larutan $\mathrm{Cu}$ (II) dan $\mathrm{Cr}(\mathrm{III}) \quad(1: 1)$ dengan konsentrasi masing-masing $60 \mathrm{mg} / \mathrm{L}$. Campuran tersebut diaduk selama 60 menit. Campuran kemudian disaring dan filtratnya ditampung untuk pengukuran kadar logam tidak terserap dengan SSA.

\section{Penentuan waktu kontak optimum}

Sebanyak 1 gram $\mathrm{SJ}_{\text {[EDTA15] dimasukkan ke }}$ dalam labu erlenmeyer kemudian ditambahkan 50 $\mathrm{mL}$ campuran larutan $\mathrm{Cu}$ (II) dan $\mathrm{Cr}$ (III) dengan konsentrasi masing-masing $60 \mathrm{mg} / \mathrm{L}$. Selanjutnya diaduk menggunakan pengaduk magnetik dengan variasi waktu kontak yaitu 30, 45, 90, 105, dan 120 menit. Larutan disaring dan filtratnya ditampung untuk pengukuran kadar logam tidak terserap dengan SSA.

\section{Penentuan isoterm dan kapasitas adsorpsi optimum}

Sebanyak 1 gram $\mathrm{SJ}_{\text {[EDTA15] }}$ dimasukkan ke dalam erlenmeyer kemudian ditambahkan $50 \mathrm{~mL}$ campuran larutan $\mathrm{Cu}$ (II) dan $\mathrm{Cr}$ (III) $(\mathrm{Cu}: \mathrm{Cr}=$ 1:1) dengan masing-masing variasi konsentrasi yaitu 20, 40, 60, 80, dan $100 \mathrm{mg} / \mathrm{L}$. Campuran tersebut diaduk selama waktu kontak optimum, 
kemudian campuran disaring dan filtratnya ditampung untuk pengukuran kadar logam tidak terserap dengan SSA. Kapasitas adsorpsi $\mathrm{Cu}(\mathrm{II})$ dan $\mathrm{Cr}(\mathrm{III})$ oleh $\mathrm{SJ}_{\text {[EDTA15] }}$ ditentukan dengan persamaan 1.

$$
\mathrm{W}_{\mathrm{ads}}=\frac{\left(\mathrm{C}_{1}-\mathrm{C}_{2}\right) \mathrm{V}}{1000 \mathrm{~B}} .
$$

$\mathrm{W}_{\mathrm{ads}}$ merupakan jumlah zat yang teradsorpsi $(\mathrm{mg} / \mathrm{g})$, B merupakan massa sampel yang digunakan $(\mathrm{g}), \mathrm{C}_{1}$ merupakan konsentrasi larutan awal $(\mathrm{mg} / \mathrm{L}), \mathrm{C}_{2}$ merupakan konsentrasi larutan akhir (mg/L), dan $\mathrm{V}$ merupakan volume larutan yang digunakan $(\mathrm{mL})$ ) (Day dan Underwood, 2002).

Untuk mengetahui pola isoterm adsorpsi $\mathrm{Cu}$ (II) dan $\mathrm{Cr}$ (III) oleh $\mathrm{SJ}_{\text {[EDTA15] }}$ perlu dilakukan uji linieritas menggunakan persamaan 2 .

$$
\text { Langmuir : } \frac{\mathrm{C}}{\mathrm{m}}=\frac{1}{\mathrm{bK}}+\frac{\mathrm{C}}{\mathrm{b}}
$$

$C$ merupakan konsentrasi adsorbat dalam keseimbangan, $m$ merupakan berat adsorbat yang terjerap per gram adsorben, $K$ merupakan konstanta keseimbanganyang berhubungan dengan afinitas adsorpsi, dan $b$ merupakan kapasitas adsorpsi maksimum dari adsorben, dengan memplot $C / m$ terhadap $C$ akan menghasilkan garis lurus dengan slope $=\frac{1}{\mathrm{~b}}$ dan intersep $=\frac{1}{\mathrm{bK}}$, sehingga tetapan $K$ dan $b$ dapat ditentukan (Bohn, 2015).

$$
\text { Freundlich : } \log m=\log K+\frac{1}{n} \log C
$$

$m$ merupakan jumlah adsorbat terjerap per satuan bobot adsorben $(\mathrm{mg} / \mathrm{g}), C$ merupakan konsentrasi kesetimbangan adsorbat setelah adsorpsi ( $\mathrm{mg} / \mathrm{L})$, $K, n$ : konstanta empiris (Do, 1998)).

\section{HASIL DAN PEMBAHASAN}

\section{Pembuatan Kurva Kalibrasi}

Pengukuran larutan standar $\mathrm{Cu}$ (II) dan Cr(III) dengan SSA pada panjang gelombang $249,2 \mathrm{~nm}(\operatorname{logam~Cu})$ dan 357,9 nm $(\operatorname{logam} \mathrm{Cr})$. Diperoleh persamaan $\mathrm{y}=0,05002 \mathrm{x}+0,01636$ dengan nilai $r$ sebesar 0,9997 untuk logam $\mathrm{Cu}$ dan persamaan $y=0,03926 x+0,01178$ dengan nilai $r$ sebesar 0,9994 untuk logam Cr yang menandakan bahwa adanya korelasi dari absorbansi dan konsentrasi terhadap kenaikan konsentrasi dan respon yang linier (Gambar 1).

\section{Konsentrasi EDTA Optimum sebagai Aktivator}

Serbuk gergaji kayu jati (SJ) diaktivasi dengan EDTA pada berbagai konsentrasi. Aktivasi dilakukan dengan perbandingan rasio massa SJ : EDTA yaitu 2:1 (SJ [EDTA5] $), 1: 1$ $\left(\mathrm{SJ}_{[\text {EDTA10] }}\right), 2: 3$ (SJ $\left._{\text {[EDTA15] }}\right)$, dan 1:2 (SJ [EDTA20] $)$. Pada saat aktivasi digunakan $20 \mathrm{~g}$ SJ yang direfluks dengan $200 \mathrm{~mL}$ EDTA.

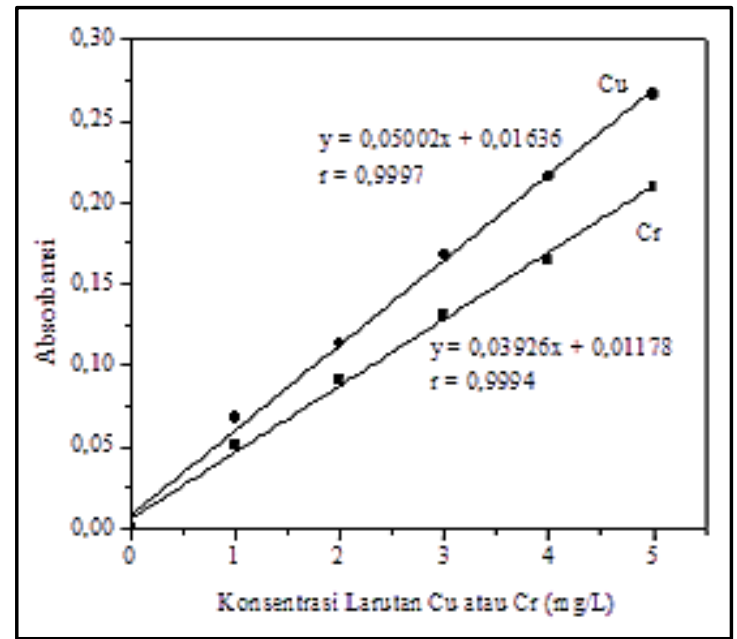

Gambar 1. Kurva kalibrasi hubungan antara konsentrasi dengan absorbansi

Untuk mendapatkan SJ aktif terbaik, perlu digunakan aktivator EDTA dalam berbagai konsentrasi, sehingga digunakan rasio massa yang berbeda untuk tiap komposisi SJ aktif. SJ aktif yang diperoleh dari masing-masing aktivasi secara berturut-turut yaitu sebanyak 19,99 g; $19,62 \mathrm{~g} ; 19,24 \mathrm{~g}$; dan 19,58 g.

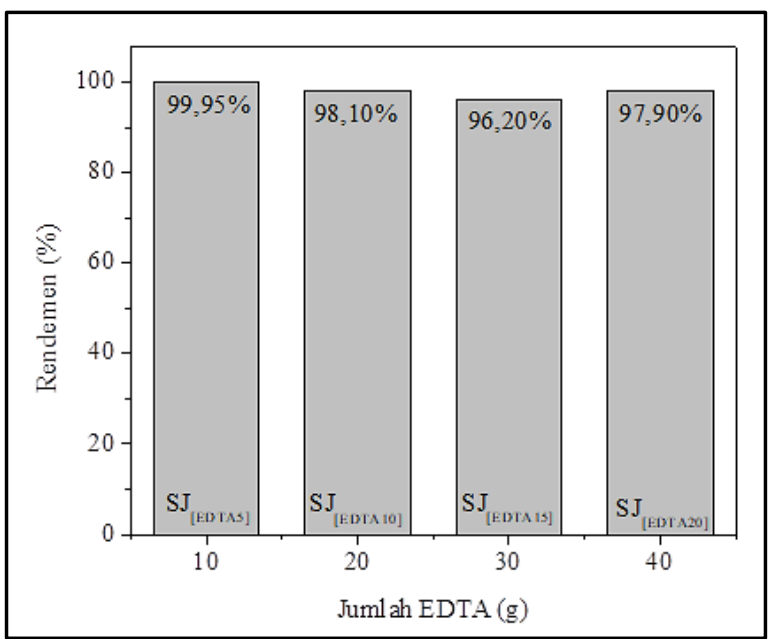

Gambar 2. Persen rendemen serbuk gergaji kayu jati teraktivasi EDTA 
Persentase rendemen dapat dihitung dan diperoleh hasil seperti pada Gambar 2. Semakin tinggi persentase rendemen yang dihasilkan menandakan semakin banyak SJ aktif yang dihasilkan. Hasil adsorpsi $\mathrm{Cu}$ (II) dan $\mathrm{Cr}$ (III) 60 $\mathrm{mg} / \mathrm{L}$ terhadap masing-masing SJ aktif dapat dilihat pada Gambar 3. Pada adorpsi $\mathrm{Cu}$ (II) dan $\mathrm{Cr}(\mathrm{III})$, jumlah zat yang teradsorpsi dalam $\mathrm{mg} / \mathrm{g}$ yang terbaik yaitu pada jumlah EDTA $30 \mathrm{~g}$. Jumlah EDTA $30 \mathrm{~g}$ merupakan SJ teraktivasi EDTA dengan perbandingan massa 2:3, dengan SJ sebanyak $20 \mathrm{~g}$ dan EDTA $30 \mathrm{~g}$ dalam $200 \mathrm{~mL}$.

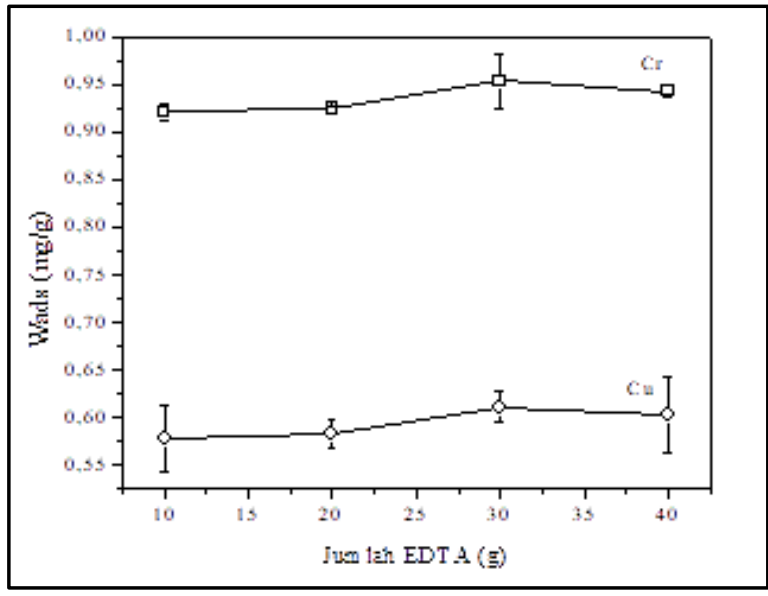

Gambar 3. Kurva hubungan jumlah $\mathrm{Cu}$ (II) dan Cr(III) yang terserap (Wads) dengan

Reaksi yang terjadi saat aktivasi dapat dilihat pada Gambar 4, yaitu selulosa serbuk gergaji kayu jati bereaksi dengan gugus karboksilat pada $\mathrm{Na}_{2}$ EDTA dan mengaktifkan gugus $\mathrm{OH}$ pada adsorben. Ketika dilakukan adsorpsi terhadap $\mathrm{Cu}$ (II) dan $\mathrm{Cr}(\mathrm{III})$, SJ aktif EDTA akan mengalami reaksi pembentukan kompleks terhadap logam.

\section{Waktu Kontak Optimum}

Penentuan waktu kontak optimum dilakukan menggunakan $\mathrm{SJ}_{\text {[EDTA15] }}$ dengan campuran larutan $\mathrm{Cu}$ (II) dan $\mathrm{Cr}$ (III) $60 \mathrm{mg} / \mathrm{L}$ pada waktu kontak 30, 45, 90, 105, dan 120 menit. Waktu kontak optimum terhadap $\mathrm{Cu}$ (II) dan $\mathrm{Cr}$ (III) yaitu pada 105 menit, dapat dilihat pada Gambar 4, kapasitas adsorpsi terbesar terjadi pada waktu kontak 105 menit terhadap $\mathrm{Cu}$ (II) dan $\mathrm{Cr}$ (III) dengan nilai 0,7852 dan $0,8984 \mathrm{mg} / \mathrm{g}$. Hal ini menandakan bahwa pada menit ke-105 telah terjadi kesetimbangan reaksi antara adsorben dan adsorbat dalam larutan.
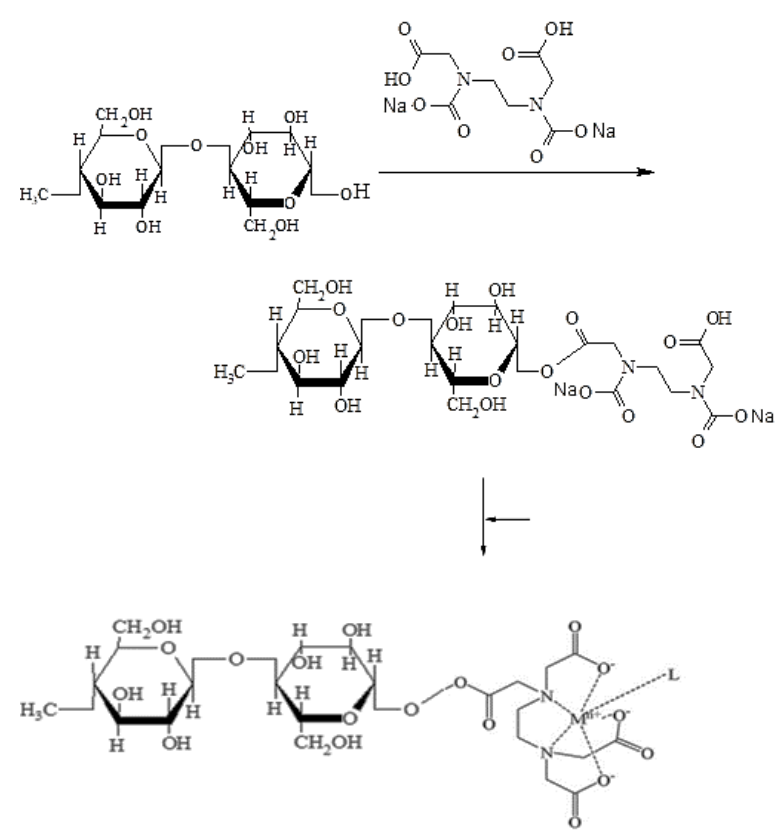

Gambar 4. Reaksi serbuk gergaji kayu jati teraktivasi EDTA dengan $\mathrm{Cu}$ (II) dan $\mathrm{Cr}$ (III) (Pereira, 2010)

Semakin lama waktu kontak maka semakin banyak partikel adsorben yang bereaksi dengan adsorbat sehingga kapasitas adsorpsinya meningkat. Terjadi penurunan jumlah adsorbat yang teradsorpsi pada menit ke-120 akibat terjadinya kejenuhan pada situs aktif adsorben yang digunakan sehingga tidak mampu lagi mengadsorpsi $\mathrm{Cu}$ (II) maupun $\mathrm{Cr}$ (III) lagi.

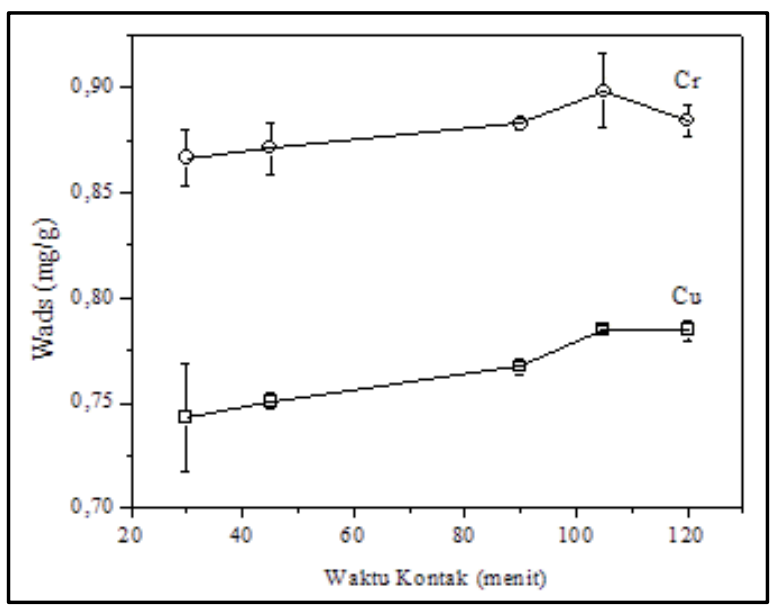

Gambar 5. Kurva hubungan jumlah $\mathrm{Cu}($ II) dan $\mathrm{Cr}$ (III) yang teradsorpsi (Wads) dengan waktu kontak.

\section{Isoterm dan Kapasitas Adsorpsi Optimum \\ Isoterm adsorpsi ditentukan dengan mengalurkan persamaan isoterm adsorpsi}


Irdhawati dkk. / Indo. J. Chem. Res., 2020, 7(2), 114-119

Langmuir dan Freundlich menjadi kurva kesetimbangan garis lurus. Model kesetimbangan ditentukan tergantung pada harga koefisien determinasi $\left(\mathrm{R}^{2}\right)$ dengan harga yang tinggi.
Gambar 5 menunjukkan bahwa jumlah logam yang teradsorpsi berbanding lurus dengan kenaikan konsentrasi baik pada adsorpsi $\mathrm{Cu}(\mathrm{II})$ dan $\mathrm{Cr}(\mathrm{III})$. Peningkatan yang signifikan terjadi pada konsentrasi $20-100 \mathrm{mg} / \mathrm{L}$.

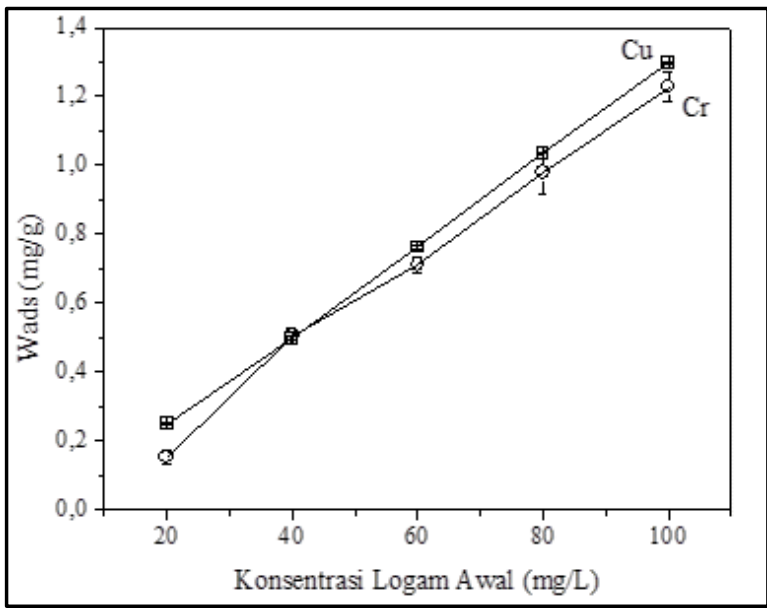

Gambar 6. Kurva isoterm adsorpsi Cu(II) dan Cr(III)
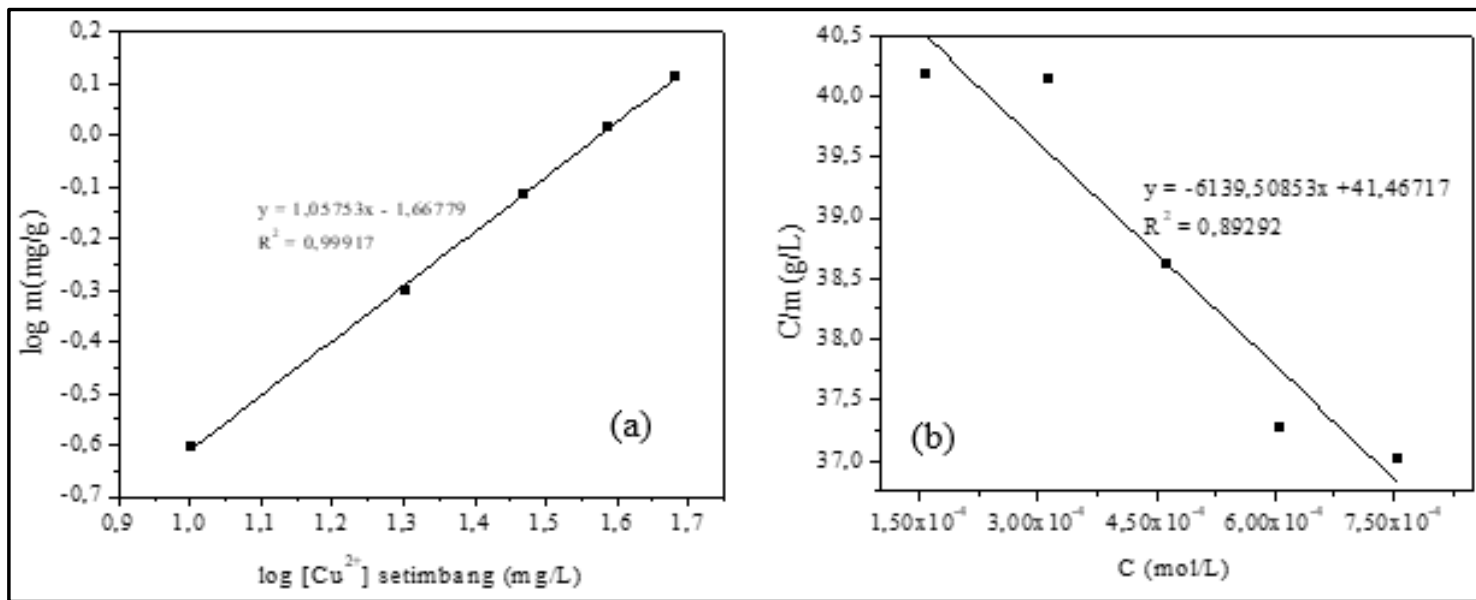

Gambar 7. Plot Isoterm Adsorpsi Cu(II): (a) Isoterm Freundlich dan (b) Isoterm Langmuir
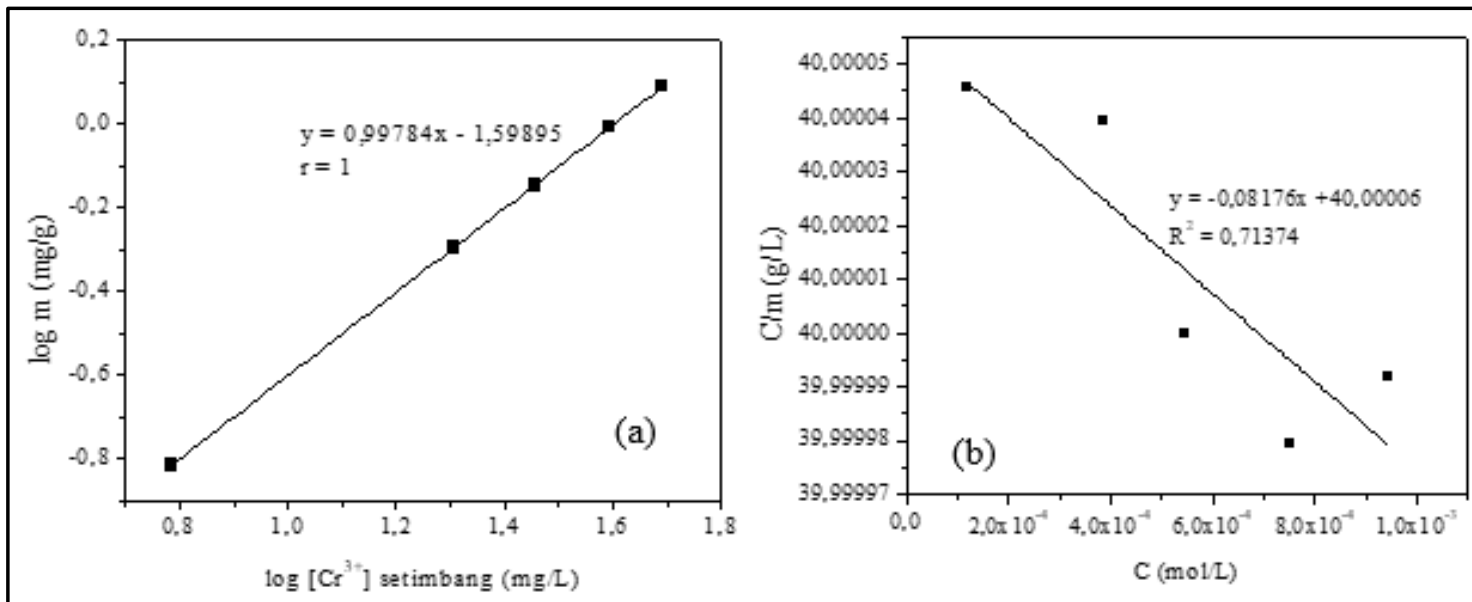

Gambar 8. Plot isoterm adsorpsi Cr(III) : (a) Isoterm Freundlich dan (b) Isoterm Langmuir 
Peningkatan terjadi akibat situs aktif pada permukaan adsorben belum jenuh, sehingga semakin tinggi konsentrasi ion logam maka semakin banyak pula molekul ion logam yang teradsorpsi. Gambar 6 menujukkan bahwa isoterm adsorpsi $\mathrm{Cu}$ (II) cenderung mengikuti pola isoterm adsorpsi Freundlich, dilihat dari nilai $\mathrm{R}^{2}$ nya yaitu sebesar 0,9992 . Hal ini menujukkan bahwa proses adsorpsi $\mathrm{Cu}(\mathrm{II})$ terjadi pada bagian permukaan adsorben yang heterogen berdasarkan adanya gugus fungsi pada permukaan adsorben tersebut. Akibatnya interaksi adsorbat dan adsorben terjadi pada afinitas yang berbeda, berdasarkan persamaan Freundlich dapat ditentukan kapasitas adsorpsi optimumnya yaitu $46,5 \mathrm{mg} / \mathrm{g}$.

Hasil penelitian lain dalam penentuan isotherm adsorpsi terhadap ion $\mathrm{Cu}$ (II) menggunakan serbuk kayu meranti mengikuti pola Freundlich dengan nilai $\mathrm{R}^{2}=0,99$ serta kapasitas adsorpsi optimum 2,74 mg/g pada temperature $30{ }^{\circ} \mathrm{C}$ (Ahmad dkk., 2009). Dari kedua hasil penelitian tersebut mempunyai pola isotherm adsorpsi yang sama yaitu Freunlich, namun kapasitas adsorpsi serbuk kayu jati lebih tinggi dibandingkan serbuk kayu meranti. Gambar 7 menunjukkan pola isoterm adsorpsi $\mathrm{Cr}(\mathrm{III})$ yang juga cenderung mengikuti pola isoterm Freundlich, dilihat dari nilai $\mathrm{R}^{2}$ nya yaitu sebesar 1. Berdasarkan persamaan Freundlich, diperoleh kapasitas adsorpsi optimum terhadap Cr(III) yaitu 39,7 mg/g.

\section{KESIMPULAN}

Berdasarkan hasil penelitian dapat disimpulkan bahwa, konsentrasi EDTA optimum yang dapat digunakan sebagai aktivator serbuk gergaji kayu jati dalam adsorpsi $\mathrm{Cu}$ (II) dan $\mathrm{Cr}$ (III) yaitu $15 \%$ (perbandingan massa SJ:EDTA $=2: 3$ ). Waktu kontak optimum pada adsorpsi $\mathrm{Cu}$ (II) dan Cr(III) yaitu pada waktu 105 menit dengan pola isoterm adsorpsi Freundlich terhadap $\mathrm{Cu}(\mathrm{II})$ dan $\mathrm{Cr}(\mathrm{III})$. Kapasitas adsorpsi optimum masingmasing logam $\mathrm{Cu}$ (II) dan $\mathrm{Cr}$ (III) berturut-turut yaitu $46,5 \mathrm{mg} / \mathrm{g}$ dan $39,7 \mathrm{mg} / \mathrm{g}$.

\section{UCAPAN TERIMA KASIH}

Penulis mengucapkan terimakasih kepada Bapak I Gede Andy Kharismayadi, yang menyediakan sampel serbuk kayu jati. Penelitian ini didanai dari Penelitian Dasar Unggulan Perguruan Tinggi, No. Kontrak 171.59/UN14.4.A/LT/2018 Tahun 2018.

\section{DAFTAR PUSTAKA}

Ahmad, A., Rafatullah, M., Sulaiman, O., Ibrahim, M.H., Chii, Y.Y., Siddique, B.M., 2009, Removal of $\mathrm{Cu}$ (II) and $\mathrm{Pb}$ (II) Ions from Aqueous Solutions by Adsorption on Sawdust of Meranti Wood, Desalination 247, 636-646

Andini, A., Irdhawati, Arsa, M., 2016, Daya Serap Kulit Kacang Tanah Teraktivasi Asam Basa Dalam Menyerap Ion Fosfat Secara Batch dengan Metode Bath, J. Kimia Riset, 1 (1), 52-57.

Bohn, H.L., McNeal, B.L., O'Connor, G.A., 2015, Soil Chemistry, Fourth Edition, A Willey Interscience Publication, New York.

Day, R.A., Underwood, A.L., 2002, Analisis Kuantitatif Ed ke-6, Erlangga, Jakarta.

Do, D.D., 1998, Adsorption Analysis : Equilibria and Kinetics, Imperal College Press, Singapore.

Fengel, D., Wegener, G., 1995, Kayu: Kimia Ultrastruktur, Reaksi-reaksi, Ed ke-1, a.b. Sastroadmijoyo, H., ed. Prawirohatmodjo, S. Gajah Mada University Press, Yogyakarta.

Harni, M.R., Iryani, A., Affandi, H., 2013, Pemanfaatan Serbuk Gergaji Kayu Jati (Tectona grandis L.f) sebagai Adsorben Logam Tinbal (Pb), http://www. repository.unpak.ac.id, FMIPA Pakuan, Bogor.

Joko, T., 2003, Penurunan Kromium (Cr) dalam Limbah Cair Proses Penyamakan Kulit Menggunakan Senyawa Alkali $\mathrm{Ca}(\mathrm{OH})_{2}$, $\mathrm{NaOH}$, dan $\mathrm{NaHCO}_{3}$ (Studi Kasus di PT Trimulyo Kencana Mas Semarang), J. Kesehatan Lingkungan 2 (2), 39-45.

Pereira, F.V., Gurgel, L.V.A., Gil, L.F., 2010, Removal of $\mathrm{Zn}^{2+}$ from Aqueous Single Metal Solutions and Electroplating Wastewater with Wood Sawdust and Sugarcane Bagasse Modified with EDTA Dianhydride (EDTAD), J. Harzadous Materials 176 (2010), 856-863.

Pratiwi, A., Yusuf, B., Gunawan, R., 2015, Analisis Perubahan Kadar Logam Tembaga $(\mathrm{Cu})$ pada Penambahan Ion Perak (Ag) dengan Metode Elektrokoagulasi, J. Kimia Mulawarman 13 (1), 1-3.

Wijayanti, Laksono, E.W., 2017, Daya Adsorpsi Adsorben Kulit Salah Termodifikasi Terhadap Krom (III), J. Kimia Dasar 6 (1), 11-18. 